\title{
ASSESSMENT OF ECONOMIC ACTIVITY IN POLAND IN THE LIGHT OF SELECTED TAX REVENUES
}

\author{
Lukasz Furman ${ }^{1}$, PhD \\ ${ }^{1}$ State Higher Vocational School Stanislawa Pigonia in Krosno
}

\begin{abstract}
Economic activity is very important today, because it allows to increase economic development and economic growth. The literature presents different approaches to the assessment of economic activity. In this article the analysis of economic activity in various regions of Poland has been undertaken. In order to assess this activity, income taxes were selected, and were considered to be the right economic barometer to identify which of the regions best develop and produce in economic activity. The presentation of this subject matter will allow for proper shaping of economic policy in Poland in future. At the beginning, the hypothesis was put forward that the economic activity in the Member of Parliament is strongly diversified. In order to verify the hypothesis, the shares in tax revenues that are transferred from the state budget to the administrative unit, i.e. the voivodeship, were selected. In particular, the analysis covered shares in income in personal income tax and corporate income tax.

The main part analyses statistical data on the development of shares in income taxes per capita in each voivodeship. The analysis covered a five-year period from 2013 to 2017 . Finally, conclusions were drawn from the analysis carried out
\end{abstract}

Key words: income tax, voivodeship, economic activity.

JEL code: H24, H25.

\section{Introduction}

Economic activity is often the subject of scientific research, which is carried out on the basis of various data. Usually, to determine the degree of economic development of a given area, data on turnover or wages are obtained. Often other data are also used, which, after proper analysis, allow to illustrate which areas have a greater economic potential. The discussed topics can be observed and analysed in different dimensions, i.e. local, regional, national or international.

In this article the topic of economic activity was presented in the regional dimension and concerned all voivodships of Poland. In order to precisely diagnose this problem, a hypothesis was put forward that there is a diversified economic activity in Poland. In order to verify the hypothesis, the method of statistical analysis of the data was used. The shares in income from income taxes for each of the voivodships were taken into account. The summary of the article contains the relevant conclusions from the analysis.

\section{Tax as a barometer of economic activity}

Economic activity is undoubtedly a factor shaping the economic development of a given region. The concept of economic activity is inextricably linked with economic development, which according to Czaplicka is considered not only a quantitative change (economic growth), but also qualitative transformation of the economy. Economic development means comprehensive changes taking place in the economy in the long term (Bakiewicz, Czaplicka 2011, p. 77, Lipton 1990, p. 77).

There are many approaches to explaining the problems of economic development, which is a complex process. Most often it is defined as the improvement of quantitative and qualitative measures, which characterize the cross-sectional socio-economic development in a given area. According to Potoczek, regional development is a permanent increase in the standard of living of the inhabitants and the economic potential of a large territorial unit (Potoczek, 2001).

\footnotetext{
${ }^{1}$ Rynek 1, 38-400 Krosno, Poland, e-mail: lukasz.furman@pwsz.krosno.pl
} 
Kudlacz, on the other hand, about regional development says that in order to get to know it, one has to trace a multidimensional process related to: economic potential, economic structure, natural environment, spatial and infrastructural development, spatial order, the standard of living of the inhabitants (Kudlacz 1999). Observing the economic potential and its structure can be done through the analysis of tax revenues from a given area. In the economic literature Joseph E. Stiglitz points out that taxes, for the most part, affect the way the economy functions, among others, the allocation of resources and the willingness to bear the risk (Stiglitz 2013, p. 50).

Existing taxes in the economy are to perform certain functions in a given economic system. Through the prism of its construction, the state may achieve various economic objectives, e. $\mathrm{g}$. through the structure of this tax and the level of taxation. Many authors believe that they are a factor in the economic development of each country (Grycuk 2010, p. 1-4).

Through the prism of tax revenues generated in a given area, we can also assess economic development, which is most often understood as quantitative and structural changes in the national economy, which are the consequence of economic growth (Encyklopedia PWN).

In order to diagnose economic activity in voivodships, in this article statistical indicators were used, taking into account income from income taxes due to the budgets of voivodships.

Individuals income is subject to different tax rates. In the case of natural persons, the following tax acts shall apply:

- Personal Income Tax Act of 26 July 1991,

- Act of 20 November 1998 on flat-rate income tax on certain income earned by natural persons. Payments of income tax on the:

- natural persons are carried out by natural persons conducting business activity which is taxed according to a progressive scale or linear scale or as a lump sum on recorded income,

- payers who, while paying any kind of remuneration to natural persons, are obliged under tax laws to calculate, withhold and collect personal income tax, and then pay it to the appropriate bank account of the tax authority.

As indicated at the beginning of this section, we apply several tax rates to the taxation of income. Persons employed on a contract of employment pay tax on their income according to a progressive scale, i. e. $18 \%$ and $32 \%$. Individuals who are self-employed may choose to tax their income according to this progressive scale or to benefit from $19 \%$ flat-rate taxation. For a selected group of individual entrepreneurs, the Polish tax system offers lump-sum taxation, which consists in taxing income according to different rates, i.e. $20 \%, 17 \%, 8.5 \%, 5.5 \%, 3 \%$, Taxation of income at such low rates is, however, subject to a revenue limit of up to EUR 250,000 per PLN.

The income tax advances established by taxpayers are paid to the tax office, which, after appropriate conversion and determination of the amount of the share in the income, transfers the calculated amount to the voivodship self-government. Advances paid by taxpayers are paid monthly according to the calculated tax advance or a predetermined advance payment, which is paid in the same amount every month. It is also possible to pay advance income tax in a quarterly period. After the end of the month, the tax office determines the amount of the share in receipts and then transfers it to the bank account of the relevant voivodeship.

On the other hand, the income of legal persons is taxed according to the Act of 15 February 1992 on corporate income tax. The basic rate in this tax is $19 \%$, but there are some exceptions to this rule. For the group of small taxpayers (income from business activity up to EUR 1,200,000) and taxpayers starting their business activity - in the year in which they started it, the rate is $15 \%$. 


\section{Rules for determining shares in income from income taxes}

The value of shares in income from income taxes transferred to the budgets of voivodships shall be determined in accordance with strictly defined rules laid down in the Act of 13 November 2003 on Income of Local Government Units.

In particular, Article 9 of the aforementioned Act specifies the methods of determining the amount of shares in personal income tax. According to it, the amount of the share: a/ the municipality's revenue from the personal income tax, which constitutes State budget revenue, is determined by multiplying the total amount of the revenue from this tax by 0,3934 and a ratio equal to the share due in the year preceding the base year of the personal income tax on natural persons residing in the municipality, in the total amount of the tax due in the same year, the amount of the contribution of the county to the income tax revenue of the State budget shall be determined by multiplying the total amount of income from this tax by 0,1025 and an index equal to the share due in the year preceding the base year of income tax on natural persons residing in the county in the total amount of tax due in the same year, c/ the amount of the voivodship's share in the revenue from personal income tax, which constitutes State budget revenue, is determined by multiplying the total amount of revenue from this tax by 0.0160 and an indicator equal to the share due in the year preceding the base year of income tax on natural persons residing in the area of the voivodship in the total amount of tax due in the same year.

The indicators listed in points a - $\mathrm{c}$ are determined on the basis of the data contained in the tax returns submitted, the amount of income earned and the annual tax calculation made by the taxpayers, as at 15 September of the base year.

In the next article 10 of the Act on income of local government units, the rules of determining income tax receipts from corporate income tax were specified. According to the envisaged rules, if a corporate income tax payer has a permanent establishment (branch) located within the territory of a local government unit other than the one competent for its registered office, the part of the income from the participation in the income tax is transferred to the budget of the local government unit in whose territory the permanent establishment (branch) is located, proportionally to the number of persons employed there on the basis of an employment contract. The legislator has also provided that shares in corporate income tax will also cover taxpayers who operate through a foreign company located on the territory of the Republic of Poland. Part of the income from the participation in the income from this tax is transferred to the budget of the local government unit in the territory of which the work is performed, on the basis of an employment contract, by persons employed by the taxpayer or by its foreign company, in proportion to the number of persons employed by the taxpayer or the foreign company on the territory of the Republic of Poland. Entrepreneurs, however, are forced to prepare and submit information to tax offices, including a list of companies (branches) and the number of persons employed under an employment contract, performing work in individual companies with the indication of local government units, in which they are located.

The presented rules of calculation of due shares in taxes constituting state budget revenue are complicated to apply and labour-intensive. In particular, it is necessary to determine the number of persons who inhabited the territory of a given territorial self-government unit. Additionally, taxpayers paying corporate income tax are obliged to submit tax information on the number of persons employed in organizational units (branches) of entrepreneurs, however, located within the territorial jurisdiction of a given self-government. Although it is an administrative activity, it takes a lot of time on the part of tax entities. Taxpayers must compile the information necessary to compile the 
information and then forward it to the competent tax authority. Failure to comply with this obligation may result in the taxpayer being punished with a penalty in the form of a penal mandate.

Therefore, the transfer of appropriate shares to local government units depends on the timely, reliable and reliable presentation of tax information by the entrepreneur to the tax office. Here, there may arise problems related to untimely submission of the tax form by the entrepreneur to the tax authority, which may significantly disturb the process of transferring by the tax accounting department the relevant shares in income taxes for a specific local government budget. The case seems to be of particular concern when the Authority does not receive the relevant documentation on the basis of which it can transfer the relevant amounts of the shares. Sometimes there are situations where tax offices transferring part of their income taxes to communes, districts or provinces have to pay interest on late transfer of shares, which is often not their fault. Such a situation worsens the state of settlements. The revenues of local government budgets in question constitute a valuable inflow of funds. From the point of view of the financial management of each local government, they are an important point in the overall budget revenue. Some municipalities or towns outdo each other in ideas on how to narrow down the value of shares in income tax receipts. They usually focus on the promotional campaign „; i live here, I pay taxes here"; . The activities are a lottery with prizes, aimed at natural persons who will register in Rzeszów. The registration will be followed by an increased share in the personal income tax to the city budget.

The Act of 13 November 2003 on the income of local government units as the source of own income of municipalities defines, among other things, shares in income from corporate income tax (CIT). At the same time, it indicates that the amount of this share amounts to $6.71 \%$ of income from CIT taxpayers with their registered office in the area of a given commune. If a CIT payer has a company (branch) located in a commune other than the commune in which it has its registered office, then a part of the income from the participation in CIT receipts is transferred to the budget of the commune in which the company (branch) is located, proportionally to the number of persons employed in it under an employment contract.

\section{Shares in income taxes transferred to the budgets of voivodships}

As part of the following chapter, statistical data from the Local Data Bank, the Central Statistical Office (GUS) on the value of shares acquired in corporate income tax by individual voivodships were analysed. The presented data are closed in the period from 2013 to 2017. Below each Table there are short conclusions concerning the analysed subject matter. Moreover, for the aforementioned period the ratios of shares in income in the income tax on natural persons per capita of the voivodship and the income tax on legal persons per capita of the voivodship were calculated. In the first of the tables, on the basis of statistical data, the amount of shares in income tax to natural persons per 1 inhabitant of a given voivodship was calculated. 
Shares of voivodships in state budget revenues personal income tax per capita

\begin{tabular}{|l|c|c|c|c|c|}
\hline \multirow{2}{*}{ WOJEWODZTWO } & $\mathbf{2 0 1 3}$ & $\mathbf{2 0 1 4}$ & $\mathbf{2 0 1 5}$ & $\mathbf{2 0 1 6}$ & $\mathbf{2 0 1 7}$ \\
\cline { 2 - 6 } & PLN & PLN & PLN & PLN & PLN \\
\hline POLSKA & 27.38 & 29.56 & 32.00 & 34.47 & 37.56 \\
\hline KUJAWSKO-POMORSKIE & 28.74 & 31.11 & 34.01 & 36.63 & 40.09 \\
\hline LUBELSKIE & 22.95 & 24.56 & 26.57 & 28.72 & 31.39 \\
\hline LUBUSKIE & 18.79 & 20.39 & 22.23 & 23.83 & 25.57 \\
\hline LODZKIE & 22.68 & 24.25 & 26.50 & 28.78 & 31.59 \\
\hline MALOPOLSKIE & 25.76 & 27.93 & 30.30 & 32.65 & 35.62 \\
\hline MAZOWIECKIE & 25.56 & 27.39 & 29.73 & 32.36 & 35.89 \\
\hline OPOLSKIE & 42.93 & 46.21 & 49.53 & 53.32 & 57.76 \\
\hline PODKARPACKIE & 22.30 & 24.26 & 25.95 & 27.95 & 30.58 \\
\hline PODLASKIE & 17.95 & 19.58 & 21.28 & 23.04 & 25.21 \\
\hline POMORSKIE & 20.26 & 21.85 & 23.73 & 25.65 & 28.06 \\
\hline SLASKIE & 27.46 & 29.58 & 32.18 & 34.80 & 38.25 \\
\hline SWIETOKRZYSKIE & 31.06 & 33.86 & 36.44 & 38.35 & 40.91 \\
\hline WARMINSKO-MAZURSKIE & 19.80 & 21.34 & 22.67 & 24.34 & 26.74 \\
\hline WIELKOPOLSKIE & 20.43 & 22.09 & 23.83 & 25.85 & 27.86 \\
\hline ZACHODNIOPOMORSKIE & 27.02 & 28.95 & 31.53 & 34.51 & 38.07 \\
\hline SOUIEI & 23.77 & 25.51 & 28.11 & 30.05 & 33.04 \\
\hline
\end{tabular}

Source: author's calculations based on Polish Statistical Office

On the basis of the analysis of the data contained in the Table above, we can state that the largest share in the tax revenues obtained from personal income tax is held by the Mazowieckie, Slaskie, Dolnoslaskie, Wielkopolskie and Mazowieckie Voivodships, respectively. The calculated indices for these voivodships allow us to state that there is a very high economic activity in these voivodships related to the employment of employees and running an individual business activity. Obtaining the highest level of the indicator in the voivodships in question is primarily related to the location of these voivodships by the main communication routes and very good development of infrastructure enabling the development of economic activity. Mazowieckie voivodship, as it reached the highest level of the indicator, shows that there is the best economic activity in its area. Achieving such a high level of the meter (above 40 PLN and 50 PLN in the last two years of the survey for the Mazowieckie Voivodeship) is an undoubted success for the Mazowieckie Voivodeship and the other mentioned. Despite such good results recorded in five voivodships in economic policy should also pay attention to the voivodships where the level of the calculated share of personal income tax is the lowest. The calculations show that the worst economic activity is in Lubelskie, Podkarpackie, Podlaskie and Swietokrzyskie voivodships. The recorded level of the indicator significantly below PLN 30 per capita, often not exceeding the average result obtained for the whole area of Poland. 
Shares in taxes constituting state budget revenues corporate income tax in 2013 - 2017

\begin{tabular}{|l|c|c|c|c|c|}
\hline \multirow{2}{*}{ WOJEWODZTWO } & $\mathbf{2 0 1 3}$ & $\mathbf{2 0 1 4}$ & $\mathbf{2 0 1 5}$ & $\mathbf{2 0 1 6}$ & $\mathbf{2 0 1 7}$ \\
\cline { 2 - 6 } POLSKA & PLN & PLN & PLN & PLN & PLN \\
\hline DOLNOSLASKIE & 105.50 & 108.20 & 118.68 & 124.97 & 140.81 \\
\hline KUJAWSKO-POMORSKIE & 173.48 & 139.24 & 169.51 & 149.39 & 180.27 \\
\hline LUBELSKIE & 79.12 & 82.39 & 86.04 & 95.81 & 93.87 \\
\hline LUBUSKIE & 58.76 & 59.96 & 56.74 & 54.85 & 61.89 \\
\hline LODZKIE & 69.02 & 75.53 & 79.45 & 85.68 & 98.06 \\
\hline MALOPOLSKIE & 96.50 & 94.90 & 105.56 & 106.24 & 106.56 \\
\hline MAZOWIECKIE & 79.35 & 85.21 & 90.97 & 106.89 & 110.54 \\
\hline OPOLSKIE & 215.83 & 233.36 & 259.03 & 272.13 & 333.91 \\
\hline PODKARPACKIE & 79.23 & 65.51 & 79.71 & 86.66 & 86.82 \\
\hline PODLASKIE & 57.16 & 62.64 & 65.34 & 68.00 & 73.26 \\
\hline POMORSKIE & 54.97 & 49.76 & 54.28 & 55.20 & 62.60 \\
\hline SLASKIE & 113.82 & 117.08 & 115.06 & 119.48 & 134.99 \\
\hline SWIETOKRZYSKIE & 85.38 & 91.07 & 94.12 & 108.34 & 119.84 \\
\hline WARMINSKO-MAZURSKIE & 48.78 & 51.77 & 57.44 & 51.02 & 50.01 \\
\hline WIELKOPOLSKIE & 50.67 & 52.33 & 55.70 & 55.43 & 52.75 \\
\hline ZACHODNIOPOMORSKIE & 105.80 & 117.46 & 137.34 & 154.26 & 163.80 \\
\hline SOUFG a & 67.34 & 69.26 & 73.62 & 78.43 & 84.11 \\
\hline
\end{tabular}

Source: author's calculations based on Polish Statistical Office

From the calculation of the ratio of income share in the corporate income tax per capita we can state that legal persons are much more active in the economy than natural persons. The level of indices in Table 2 is in some cases several times higher than the value of indices located in Table 1. Among the most economically active voivodships (the level of the index above PLN 100) are: Mazowieckie in the years 2013-2017 the level of the index in the range of PLN 200 to PLN 300. In 2017, the indicator exceeded PLN 300, which indicates a very high economic activity. For the Mazowieckie Voivodeship, the height of the achieved indicator can be explained by the fact that the capital city of Warsaw is the place where many large enterprises, including large companies with international capital, have their registered office. A large concentration of economic units influences the largest economic activity of the Mazowieckie Voivodeship.

The lowest economic activity was in the following voivodships: Swietokrzyskie and Lubelskie (the index obtained in the years under review was below PLN 60). It is worth stressing that in the years 2013-2017 the average index for the whole Poland ranged from PLN 105. 50 to PLN 140. 80 per 15 voivodships. Such a level of the indicator was achieved only in four voivodships, i. e. Mazowieckie, Wielkopolskie, Pomorskie and Dolnosląskie. As a result, the most active economic entities are legal entities from the above mentioned voivodships.

\section{Summary}

The analysis carried out in the scope of economic activity in individual voivodships of Poland allows to draw a few conclusions, i.e. :

1) the most important from the point of view of transfers received from the state budget are the shares in corporate income tax, as in the analysed period of 2013-2017 the voivodeships recorded the highest income per capita on this account; 
2) In the area of income from shares in personal income tax, it can be stated that they provided much less income for the budgets of voivodships than shares in corporate income tax;

3) changes in the economic policy shaping economic activity of entrepreneurs need first of all the voivodeships reaching the lowest indices, i. e. Lubelskie, Podkarpackie, Podlaskie and Swietokrzyskie; this concerns both the reference to natural persons and legal persons conducting business activity;

4) the analysis indicates where entrepreneurship should be developed in order to achieve sustainable economic development in Poland and economic activity is so highly diversified.

\section{Bibliography}

1. Local Data Bank, Available www.stat.gov.pl,

2. Bakiewicz, A., Czaplicka, K. (2011), Wzrost i rozwoj gospodarczy w krajach rozwijajacych sie [w:] R. Piasecki (red.), Ekonomia rozwoju, PWE, Warszawa, p. 70-93.

3. Grycuk, A., Podatek, CIT jako narzedzie polityki gospodarczej, Biuro Analiz Sejmowych, Infors Zagadnienia spoleczNo - gospodarcze $\mathrm{nr} 4$ (74), 18.02.2010 r., p. 2.

4. Lipton D., Sachs J., Fischer S., Janos K., (1990), Creating a Market Economy in Eastern Europe: The case of Poland, Bookings Papers on Economic Activity, Volume 1990, Issue, p. 77.

5. Kudlacz, T., (1999), Programowanie rozwoju regionalnego, Wydawnictwo Naukowe PWN, Warszawa, p. 150.

6. Marczak, L., (2007), W sprawie klasyfikacji dochodow jednostek samorzadu terytorialnego [w:] Patrzalek L., Stan i kierunki rozwoju finansow samorzaądu terytorialnego, Wydawnictwo WSB Poznanń - Wroclaw, p. 45.

7. Nojszewska, E., (2002) Podatek dochodowy jako narzedzie polityki gospodarczej, Szkola Głowna Handlowa w Warszawie, p. 87.

8. Potoczek, A., (2001) Programowanie rozwoju lokalnego i regionalnego jako zadanie samorzadu terytorialnego, [w:] Potoczek A., Stymulowanie rozwoju lokalnego - perspektywa społeczna i organizacyjna, Regionalny Osrodek Studiow i Ochrony Srodowiska Kulturowego w Toruniu, Torun p. 15.

9. Stiglitz, J.E. (2013), Ekonomia sektora publicznego, PWN, Warszawa.

10. Wyrzykowski, W., Podatkowe uwarunkowania rozwoju przedsiebiorczosci w Polsce, Wydawnictwo Politechniki Gdanskiej, 2013. 